\title{
Crossing Borders: Anti-Fascist Action (UK) and Transnational Anti- Fascist Militancy in the 1990s
}

\section{Nigel Copsey}

[...] AFA must begin the task of exporting the fundamentals of militant anti-fascism to Europe. Pound for Pound, AFA is probably the most effective anti-fascist organisation in Europe. ${ }^{1}$

The historiography of militant anti-fascism in post-war Europe is almost non-existent. What we know about this subject is derived largely from accounts written by former activists. ${ }^{2}$ Scholarly study of contemporary anti-fascism is a rarity and even when the subject is broached, it is from a nation-bound perspective. ${ }^{3}$ International let alone transnational studies are few and far between. ${ }^{4}$ Yet anti-fascism is quintessentially (although not exclusively) an activity of the Left, and the 'Left, after all, has been one of the most transnational phenomena in the modern world' ${ }^{5}$ For sure, as the other contributors to this special issue demonstrate, anti-fascism has expressed itself historically as a cross-border, transnational phenomenon. But if undoubtedly true for the heyday of fascism, one question that still needs to be asked is: 
how true is this for more recent decades when fascism no longer possessed epochal significance?

This article considers the development of transnational militant anti-fascism in the 1990s with reference to Britain's Anti-Fascist Action (AFA). It probes cross-border exchanges between AFA and the German militant anti-fascist group, the Autonome Antifa (M) (AA (M)), before moving on to reflect on the importation of Anti-Fascist Action to the Irish Republic. The most significant finding to emerge from this case study is that transnational exchange was undoubtedly taken seriously by militant anti-fascists in the 1990s but critical political, ideological, and cultural differences rendered Anglo-German crossborder co-operation less effective than it could otherwise have been. As for the introduction of AFA to the Irish Republic, this reveals itself as a strange case indeed not least because unlike both Britain and Germany, Ireland had no organised far-Right street presence.

Elsewhere I have expanded on the concept of anti-fascism, and proposed (tentatively) a new anti-fascist 'minimum'. ${ }^{6}$ My work calls attention to an array of anti-fascisms, to antifascism in the plural. Accordingly, militant anti-fascism should be understood as just one particular form of anti-fascism (and certainly not the only 'authentic' type). More often than not associated with the radical Left, this variety of anti-fascism might be considered a form of 'revolutionary anti-fascism', an anti-fascism conceptualised in terms of a three-way, or tripolar struggle where the other two adversaries comprise the state/capitalism as well as the fascists themselves. ${ }^{7}$ Militant anti-fascists will usually combine physical confrontation against fascists at street level with ideological struggle not only against fascism but also against the capitalist state (which supposedly begets fascism). Yet there have been militant anti-fascist groups in the past, such as Britain's post-war 43 Group, which have been prepared to use violence and yet still remain ostensibly 'non-ideological', calling on the state 
to proscribe fascist activity. ${ }^{8}$ Even militant anti-fascism can take different forms; it is not always strictly synonymous with 'revolutionary anti-fascism'.

\section{'Let's get physical': the origins and development of Anti-Fascist Action}

Anti-Fascist Action was originally launched in London in 1985 as a non-sectarian successor to the Anti-Nazi League (ANL). ${ }^{9}$ The ANL, originally established in 1977, had grown into Britain's pre-eminent anti-fascist movement, widely credited for inflicting major blows on the electoral aspirations of the National Front (NF) in the late 1970s. But by the early 1980s, with Britain's electoral far Right in disarray, the ANL had fallen into abeyance. ${ }^{10}$ Formed from various anti-racist and anti-fascist groups, AFA's founding statement from 1985 acknowledged the need to 'oppose racism, and fascism, physically on the streets, and ideologically'. It also declared itself non-sectarian, organised on 'democratic lines, with equal representation for all groups involved'. ${ }^{11}$ Led by a secretariat - the national secretary was anti-racist campaigner, and future Labour Party leader Jeremy Corbyn - AFA counted 4,000 supporters at its launch. ${ }^{12}$ However, this original AFA unravelled due to internal tensions between militant anti-fascists and more moderate anti-racists. 'The basic contradiction, from which everything else flowed', we have been told, 'was between the opposing concepts of AFA as a militant action group and AFA as just another law abiding anti-racist protest group independent from political affiliations' ${ }^{13}$ By 1988, fractured by in-house sectarianism, AFA had all but collapsed.

The following year, however, AFA was resurrected as a militant, physical force antifascist group. At its peak during the mid-1990s, this re-launched AFA comprised some 35-40 
branches across Britain with notable activist strongholds in London, Manchester, the Midlands, Glasgow and Edinburgh. It published its own magazine called "Fighting Talk" the hard-hitting title of a controversial slot given to the group on BBC2's Open Space programme in May 1992. ${ }^{14}$ The group's trademark was regular low-level street confrontations with the far Right, principally the British National Party (BNP), which had by the early 1990s eclipsed the NF as Britain's premier extreme-Right party. ${ }^{15}$ The BNP numbered in the region of 3-4,000 members (compared to the NF's few hundred) and had become particularly active in south and east London, parts of the east Midlands, and in the north. In what Mark Hayes aptly described a 'clandestine turf-war', ${ }^{16}$ street clashes with the far Right were directed by AFA's "fighting stewards", controlling 'anything from 20 to 150 people in street confrontations'. ${ }^{17}$ Yet once the BNP withdrew from the streets in 1994, opting instead for more conventional electoral activity, AFA's militant anti-fascism was redundant. With AFA having seemingly served its purpose - it was the BNP which threw in the towel ${ }^{18}$ - some (though not all) anti-fascist militants shifted their priorities toward electoral involvement in a community-based working-class initiative known as the Independent Working-Class Association. Struggling for an identity, AFA disbanded altogether in $2001 .{ }^{19}$ When Anti-Fascist Action had been re-launched in 1989, it had been the work (primarily) of Red Action (RA), a hard-line, semi-paramilitary Marxist group. Now defunct, RA had been formed in 1982 by militant anti-fascists who had been expelled from the Trotskyist Socialist Workers' Party (SWP) for partaking in physical force, anti-fascist 'fighting groups' (or 'squads'). ${ }^{20}$ The SWP, the mainstay of the 1970s ANL, drove out the 'squadists' for replacing mass political action with 'terrorism'. 'We should never have survived', declared one RA activist, 'We didn't have the brains or the organisational abilities. We just wanted to meet the fascists head on. We're the abortion that lived' ${ }^{21}$ Whilst Red Action had been part of the original AFA (indeed, it had made the initial running in 
establishing AFA in 1985), it had little time for the moderate, 'bureaucratic' anti-racists who fronted AFA, and spent the next three years 'fighting a constant rearguard battle to keep AFA true to its founding statement of confronting fascists physically and ideologically'. ${ }^{22}$ Modest in number, almost certainly no more than a few hundred, the RA membership was predominantly white, male, and drawn from the manual working-class. Two issues were identified with RA in particular. The first was militant, physical force anti-fascism; the second was support for the Irish republican cause, including backing both the Irish Republican Army (IRA) and the Irish National Liberation Army (INLA). ${ }^{23}$

In re-launching AFA, RA's principal objective had been to form a militant 'united front' of anti-fascists prepared to counter fascism not only physically on the streets but also ideologically - winning the hearts and minds of the white working class. Simply put, AFA saw fascism as reactionary, ultra-conservative, and anti-working-class. It applied a 'twintrack' strategy: physical confrontation combined with ideological struggle. AFA not only wanted to restrict, contain, and ultimately eradicate fascist activity through a physical war of attrition with fascists on the streets, it also counteracted fascist propaganda, typically through public-speaking, organising concerts and other events, and leafleting working-class housing estates. Following its 1989 re-launch, AFA encompassed a wider range of activists than Red Action alone, consisting of an alliance of various hard-left Marxist and anarchist groups, as well as many non-aligned, 'single-issue' anti-fascists. Organisationally, AFA was a decentralised federation, with groups stretching from Scotland to the English south coast. AFA in the north came together as a 'Northern Network' but London AFA, dominated by Red Action, produced AFA's magazine Fighting Talk, and it remained the driving force behind AFA at national level. ${ }^{24}$ This dominance (RA provided the backbone of AFA's 'fighting stewards') did occasion tensions within the organisation, however. In 1994 for example, Birmingham AFA asserted its independence, changing its name to Birmingham 
Anti-Fascist Alliance. ${ }^{25}$ Nonetheless, AFA remained the foremost organisation on the militant wing of Britain's anti-fascist movement.

\section{'For the anti-fascist resistance': the origins and development of the Autonome Antifa} (M)

Responding to the electoral breakthrough of the Republikaner in 1989, Germany's reunification, and a dramatic escalation in racist violence (epitomised by far-right attacks on refugees in Hoyerswerda, Rostock, Mölln and Solingen), militant anti-fascist (or 'antifa') ${ }^{26}$ groups sprung up across Germany. One such group was Göttingen's Autonome Antifa (M). Formed in 1990 (the designation ' $M$ ' apparently referring to the day, Mittwoch, on which the anti-fascists met in Göttingen's JuZI youth centre), this militant anti-fascist group had its origins in the city's autonome (autonomous) scene. The 'autonomists, ${ }^{27}$ wanted to liberate themselves from capitalism through direct forms of immediate emancipatory action, achieving self-liberation in 'domination-free' spaces. They eschewed hierarchical organisation, were anti-patriarchal, anti-imperialist, did not adhere to a single ideology, and rejected traditional forms of workers' struggle, that is to say, they abstained from factorybased agitation. Looking neither to Moscow or Beijing, subscribing to a 'vague anarchism', the autonomous movement ditched the Leninist concept of the vanguard party. Rather than adhere to the discipline of the vertical party-model, autonomists favoured horizontal relationships. Their belief was that if one local group acted spontaneously then others would be inspired to follow. The expectation was that this 'event-driven' chain would build 'counter-power' and bring about social revolution 'from below' ${ }^{28}$ 
Until the mid-1980s anti-fascism had been a secondary concern for West Germany's autonomous movement. As Ben Mercer has recently pointed out, if 'anti-fascism' had been regularly invoked by West German student protesters in the 1960s as a manifestation of their anti-authoritarianism, after 1968 its value would diminish:

[...] seeing fascism everywhere also proved highly tendentious and did not prevent protest movements from developing their own hierarchies and authoritarianisms. One effect of the incessant invocation of fascism was its decline in value. As the student movements themselves had noted when they bothered to write seriously about the issue, police violence was hardly the prerogative of fascist regimes. Despite repression, there was no imposition of fascist dictatorships in the 1970s in Western Europe. ${ }^{29}$

Of greater significance in the 1980s were anti-nuclear campaigns, anti-militarism, squatters' struggles, and opposition to Startbahn-West (a western runway extension at Frankfurt airport). It reveals much that in the first comprehensive account of Germany's autonomous movement, published in 1990, anti-fascism is conspicuously absent. ${ }^{30}$ This is not to say that during the 1980s autonomists refrained from anti-fascist activity. The death of thirty-six yearold anti-fascist activist Günter Sare at a demonstration against the extreme-Right NPD Nationaldemoktratische Partei Deutschland (National Democratic Party) in Frankfurt in September 1985 occasioned riots across a number of West German cities. In April 1986 an 'autonomous commando' calling itself 'Revolutionary Anti-Fascists - Fire and Flames' firebombed a barn in Mainz-Gonsenheim near Frankfurt. Neo-Nazis had been using the barn as a site to celebrate the annual anniversary of Hitler's birthday. In June 1986 in Stuttgart autonomous anti-fascists successfully mobilised against the first ever national congress of the 
neo-Nazi FAP (Freiheitliche Deutschen Arbeiterpartei, Free German Workers' Party). Over the next year or two, a series of anti-fascist counter-mobilisations followed. Nonetheless autonomous anti-fascists soon found themselves isolated. Ignored by the mainstream Left Social Democrats and the trade unions - mainstream Leftists favoured the 'legal' anti-fascism of the GDR-sponsored Vereinigung der Verfolgten des Naziregimes - Bund der Antifaschistinnen und Antifaschisten (Association of Persecutees of the Nazi Regime/Federation of Antifascists, VVN-BdA) $)^{31}$ - more and more autonomists grew tired of 'riding all over [West] Germany trying to break up Nazi meetings' ${ }^{32}$ With the militant antifascist movement on the wane at federal level, in the city of Göttingen in Lower Saxony, autonomous anti-fascists looked to build a more lasting base structure, and

[...] win acceptance and a place for autonomist antifa politics among broader circles. The main idea was to break out of political isolation, because only by working together with different social forces would it be possible to halt the expansion of neofascism. At that time, neo-fascism was not generally regarded a social problem. The media spoke only of a few isolated incidents. Confrontations between anti-fascists and neo-Nazis were portrayed as unpolitical fights between rival youth gangs. ${ }^{33}$

Anti-fascism is a reactive phenomenon and its various manifestations ebb and flow according to the nature of the observed stimulus ('fascism', however understood). The primary catalyst in the formation of the AA (M) had been the tragic death of a young antifascist. On 17 November 1989 anti-fascist student, Cornelia (Conny) Wessmann, had been tragically killed following a clash between anti-fascists and riot police in Göttingen. Wessmann was knocked down by a car as she fled from a riot police baton charge. For several days a vigil occupied the site where Wessmann died. After riot police broke up this 
vigil on 20 November, five days later 18-20,000 people marched through the city. As this mass protest disgorged, a neo-Nazi skinhead stabbed and seriously injured a young man near Göttingen's train station. The police refused to accept that the attack was politically motivated and the assailant was never arrested. ${ }^{34}$ Wider developments contributed too, not least Germany's reunification. In 1990 Göttingen's autonomous anti-fascists set about agitating against reunification under the slogan "Nie wieder Deutschland!" (Germany Never Again!). ${ }^{35}$ Germany's reunification was read as imperialist 'annexation' - the precursor to a 'Fourth Reich'. In March 1990, a pamphlet calling for a demonstration in Göttingen against the 'annexation' of the German Democratic Republic was signed by the "Autonome Antifa (M)", the first time that the group's name had appeared in public. ${ }^{36}$

One of the characteristic features of the autonomists was their appearance as a "Schwarzer Block" at the head of demonstrations (a block of activists menacingly dressed all in black, wearing balaclavas and motorcycle helmets. Activists would sometimes carry clubs). This (illegal) tactic supposedly served several functions. At the symbolic level its purpose was to show that autonomous anti-fascists did not recognise the state's monopoly on violence. On a practical level it offered protection against surveillance and police action, as well as offering an obvious safeguard against fascist attacks. It could, of course, be construed as representing something far more sinister and subversive. The fact that it gave anti-fascists the freedom to throw signal flares and firecrackers without being identified hardly assuaged this impression. Yet despite retaining this highly distinctive and controversial tactic, Göttingen's autonomist anti-fascists wanted to reach out to a wider coalition of more moderate leftist forces. Drawing lessons from its past isolation, from the very beginning the group engaged in local media campaigns, making itself available for interviews, allowing photographers and journalists to record its activities. The group also placed special emphasis on an Agitprop cultural-political initiative known as "Kunst and Kampf" (Art and Struggle) - 
visual-artistic representations of anti-fascism in the form of posters, brochures, theatrical events and exhibitions. ${ }^{37}$

Arising from growing recognition that anti-fascists needed to counter neo-Nazi activity more effectively on a national level, in 1992, the peak year of racial violence in the newly unified Germany, ${ }^{38}$ AA (M) led in the creation of the Anti-Fascist Action/Nationwide Organisation (Antifaschistische Aktion/Bundesweite Organisation, AA/BO). This was an umbrella organisation, founded in Wuppertal, of around a dozen regional 'antifa' groups (rising to seventeen by the end of 1995). To prevent hierarchies from being established, the organisation was based on the principle that each constituent group would send delegates to a nationwide meeting. As many women as men should attend and delegates should rotate. ${ }^{39}$ Building upon the idea of opening up to the outside - outlined by the AA (M) in an important 1991 discussion paper - the goal was to use militant anti-fascism as the vehicle for a broaderbased revolutionary counter-culture. ${ }^{40}$ Yet no binding definition of what was meant by antifascism was forthcoming and differences soon emerged over the organisation's short, medium and longer-term goals. ${ }^{41}$ Nonetheless, over the course of 1993-94 the AA/BO cooperated on a series of successful inter-regional demonstrations, including one in Adelebsen near Göttingen in 1993, and another in Northeim, Göttingen in 1994. These mobilisations (under the motto 'Against the Fascist Centres!') would typically attract around 2,000 participants.

It is never easy to be precise over the scale of militant anti-fascist activity, or the numbers of people involved. However, one anti-fascist activist has referred to an 'official figure' of 398 'militant actions against fascists' in the Federal Republic in the peak year of 1992 (a well-known far-Right extremist was killed by anti-fascists in Berlin). ${ }^{42}$ That year the numerical strength of autonomists was put at $5,000 .{ }^{43}$ The figures for two years later, provided by Federal Office for the Protection of the Constitution (BfV), counted the 
violent/militant extreme Left at $6,700^{44}$ (by way of comparison, the German authorities estimated that the number of right-wing extremists in 1994 was 41,500, with 5,600 classified as 'militant skinhead'). ${ }^{45}$ As for the AA (M) itself, about forty activists belonged to the group in 1994, almost all middle-class students. ${ }^{46}$

\section{The (twisted) road to transnational co-operation}

In their understanding that fascism was not just a national or German problem but a systemic problem of global capitalism, Göttingen's autonomists were keen to foster international solidarity with militant anti-fascist groups outside the Federal Republic. It was to this end that the group dispatched a letter of invitation to Red Action in 1992,

Dear Red Action,

You may have heard about Rostock (East Germany) and the racist/fascist mob burning down homes for asylum-seekers and refugees.

In these days with fascism so big in Germany and the whole of Europe, it's ever so important for us to get help from comrades from other countries! That would be in our case Red Action delegates participating in our demo and cultural events, possibly holding a short speech on the demo.

Yours, Autonome Antifa,

Göttingen. ${ }^{47}$ 
A number of other international groups were also invited to join with the AA (M) in demonstrating in Göttingen on 2 October 1992 (to protest against the day of German Reunification). The slogan of the demonstration was "Create Anti-Fascist Unity - The Future Belongs to Us!" Delegations from Denmark, Italy and France took part whilst others sent comradely messages of support. For whatever reason, Red Action did not.

Yet this does not mean to say that AFA paid no attention whatsoever to transnational activity. For during 1992 AFA had been participating in an embryonic European militant anti-fascist network. In fact, links with the militant French anti-fascist group SCALP-Reflex (Section carrément anti-Le Pen) had already been established. ${ }^{48}$ In 1989 French militants had written to RA proposing a gathering of radical anti-fascist groups. ${ }^{49}$ Copies of REFLEXes magazine were sent to AFA branches and copies of Fighting Talk were exchanged in return. An Anti-Fascist German Solidarity Fund was also set up by Tyne and Wear Anti-Fascist Association $^{50}$ (affiliated to AFA's Northern Network) in response to the upsurge in far-Right activity after German reunification. But it was the visit to London of Jean-Marie Le Pen in December 1991 and the launch of a new (rival) campaign group, the Campaign Against Fascism in Europe (CAFE), ${ }^{51}$ that prompted AFA to designate one of its activists as an international liaison officer. ${ }^{52} \mathrm{AFA}$ also had to face up to competition in this sphere from the Anti-Nazi League, relaunched by the SWP in 1992. An ANL contingent had attended a recent demonstration against the Front National in France and had distributed a leaflet in French entitled "Comment Arreter Le Pen" (How to Stop Le Pen). For AFA, this was a deliberate ploy by the ANL to take-over Europe's anti-fascist movement. ${ }^{53}$ Elsewhere, a further rival transnational anti-fascist movement entered the arena in the form of the Militant Tendency's Youth Against Racism in Europe (YRE).

Yet AFA saw itself as the pre-eminent anti-fascist group in Britain, and it wanted that to be recognised internationally (it felt in danger of being left behind by rival groups on the 
European stage). ${ }^{54}$ So in May 1992 AFA accepted an invitation to attend a European antifascist/anti-racist conference in Eindhoven, which had been called to form a European antifascist movement on the basis of a manifesto drafted by the Anti-Fascist Front of Antwerp. ${ }^{55}$ But AFA had objected to the 'series of liberal demands on the state to criminalise fascists and thus defeat them' ${ }^{56}$ As a result AFA, alongside other militant anti-fascist groups broke away and held an impromptu alternative conference. This resulted in the launch of a new militant anti-fascist network, the European Anti-Fascist Infos Network. Significantly, the British contact for this network was not London AFA but AFA's branch in Leeds, northern England (a Leeds AFA organiser could speak French and had personal contacts with people at SCALP-Reflex). ${ }^{57}$

The objectives behind this embryonic transnational anti-fascist network had been to exchange information and ideas, and where possible offer mutual solidarity and support. Each group in the network agreed to produce and circulate its own information bulletin. However, no international bulletins were ever compiled for AFA's magazine, Fighting Talk. Their absence was raised as a point of concern by Leeds AFA in June 1993 when it objected to Fighting Talk becoming nothing more than the mouthpiece of London AFA (that is to say, Red Action). To make matters worse Leeds AFA had paid for the latest issue of the magazine. ${ }^{58}$ Although an AFA delegation did attend the next network conference in Amsterdam in September 1993, AFA's engagement with this particular transnational network soon ended.

Given the internal criticism that was being voiced by Leeds AFA, London AFA was keen to assert itself as the organisation's 'international contact'. So it was somewhat fortuitous that a member of the AA (M) sojourning in London in 1993 had made contact with London AFA. The result of this contact was that London AFA offered to host a representative of the AA (M) on a nationwide speaking tour in 1993. The co-founder of the AA (M), Bernd 
Langer, availed himself of the opportunity and spoke at AFA events in several cities including London, Liverpool, Manchester, York and Newcastle. An anonymous interview with Langer also appeared in Fighting Talk (issue 6:6-8). This article was the first of a series of "Germany Calling” magazine features penned by the Autonome Antifa. Translated from German into English by two militants from the United States who were in Göttingen at the time, the column ran from issue six in 1993 through to issue thirteen in $1996 .^{59}$

In September 1993 the AA (M) invited an AFA delegation to participate in a protest demonstration on the eve of the third anniversary of German reunification. The invitation letter - "Greetings from Göttingen" - was reproduced for inclusion in Fighting Talk. ${ }^{60}$ Two London AFA delegates attended (one male, one female). On their arrival in Germany, Bernd Langer recalls,

There had been organised discussions to get to know each other. The conversations showed up content discrepancies with the (male) delegate from London. On the one had he maintained views about the "working class" nobody else was able to share. On the other hand he was wasn't open to important content discussions [...] There had been a discussion about the relationship between patriarchy and fascism [...] He tried to cut this question with the comment, "this would be as important as the question of whether someone eats beef or is a vegetarian". ${ }^{61}$

An obvious point that needs to be made here is that there was not a comparable autonomist movement in Britain. Within Britain's radical-Left oppositional culture, although there was a strand of individual libertarianism evident in anarcho-punk, class politics remained central. ${ }^{62}$ For a group like Red Action, any sustainable leftist group had to root itself in working-class communities. RA was disdainful of the alternative lifestyles of 
anarcho-punk and whilst willing to work operationally on the streets with anarchists (RA shared anarchism's decentralised anti-capitalism), it had little time for 'identity' politics around race, gender and sexuality. If RA had some issues with anarchists in Britain, it is unsurprising that they also had issues with the German autonomists, whom shared some of the political, cultural, and lifestyle characteristics of Britain's home-grown anarchists. ${ }^{63}$ 'There's nothing wrong with being middle class, it's just there's something wrong if they can't attract working-class people', one RA activist declared. ${ }^{64}$ But as Bernd Langer had already explained to readers of Fighting Talk, when it came to the autonomous movement in Germany, 'Most of the political activists have a middle class background, few workers are involved in the movement, they are rather the exception. The working class plays no part in the anti-fascist struggle' ${ }^{65}$

Differences between the demonstration cultures of both groups were in evidence as well. This was reflected in the fact that the London AFA delegates, unlike the delegates from other countries, did not join the Schwarzer Block but joined the block behind dressed in 'normal' clothing (some RA members favoured the 'casuals' look adopted by British football hooligans and by their opponents on the far Right, such as Combat 18). Nonetheless, one AFA delegate did speak at the end of the demonstration. Welcoming the formation of the German Anti-Fascist Action/Nationwide Organisation, the AFA delegate called on militant anti-fascists to end their isolation by working not only within national borders but also across national borders. 'This is why we are here today. It is only a small step, but it is a small step in the right direction $[\ldots]^{96}$

Notwithstanding obvious cultural differences between their respective milieus, they both shared the same arena of struggle and contact between the two groups continued. In July 1994 a new development threw their common interest back into sharp relief when the homes of seventeen people (including Bernd Langer) suspected of being members of the Autonome 
Antifa were raided by police. The AA (M) had come under investigation according to paragraph 129a of the German criminal code (that is to say, in relation to propaganda for, support of, or membership of a terrorist organisation). The raids stemmed from a public discussion that the group had organised with two former Red Army Faction prisoners and the editor of the magazine 'Clockwork 129a' in May 1993. Prosecutors claimed that the group's poster advertising the event gave support for terrorism. In June 1995, however, the charges relating to article 129a were thrown out by the State Supreme Court in Celle in Lower Saxony. An appeal was lodged by prosecutors and the federal court ruled that a trial should still proceed against the defendants on charges of forming a criminal organisation. For it be defined as a 'criminal organisation', the AA (M) had been charged with violation of public assembly laws, specifically in reference to the 'Schwarzer Block'. This, the authorities claimed, gave the impression of building a private army and violated the ban on uniforms. The state's objective, according to the Autonome Antifa, was the criminalisation of both the organisation and its politics.

For AFA, events in Göttingen hit home. London AFA immediately drew parallels with its own experience of 'state repression'. In 1992 a leading member of AFA, Gary O'Shea, had been subject to a charge of conspiracy to cause violent disorder. The charges had resulted from disturbances at a fascist meeting at London's Kensington Town Hall in late 1991. The prosecution case collapsed but throughout the trial the Detective Chief Inspector had apparently browsed through a file marked "Operation Blackshirt". ${ }^{67}$ AFA believed that this file represented an on-going attempt by the British state to isolate and criminalise AFA through the use of selective arrests. AFA would also suspect that the security services had attempted to entrap anti-fascist militants during a 60,000-strong anti-fascist demonstration against the BNP's bookshop/HQ in Welling in south east London in October 1993. Selective arrests, AFA believed, were intended to blunt its 'cutting edge', 'intimidate the periphery', 
and thereby 'bolster the reputation of a more moderate or bogus' rival organisations, such as the recently relaunched (and more moderate) Anti-Nazi League (ANL). ${ }^{68}$ London AFA's statement of support to their German comrades read,

[...] Repression is the state's answer to the political success of Autonome Antifa (M) in Lower Saxony. The dawn raid is testimony to, and punishment for, your political influence in the area.

This is a strategy with which we in Britain are also familiar. Here, the object of the state's strategy is to demonstrate that confrontational tactics against the far-right do not work. The expectation then is that either militant and effective tactics are abandoned and we operate after the fashion of say the Anti Nazi League; or we become totally clandestine which would deny us any political profile and the criminalisation process started by the state is completed by ourselves.

The message ended with the prediction that 'Your reality today is ours tomorrow' ${ }^{69}$ For AFA, events in Lower Saxony represented a serious threat to militant anti-fascists not just in Germany but everywhere.

In the wake of the July 1994 raids, AFA asked Langer and another AA (M) representative to return to London and organised a public meeting in the capital to publicise the cause of their German comrades. Significantly, discussions had taken place regarding the possibility of co-hosting an international conference in order to set up a new international militant anti-fascist network. For AFA, a central aim of this broader transnational cooperation was to overcome the 'isolation, oppression and even criminalisation' faced by militant anti-fascists. ${ }^{70}$ It was agreed that a conference manifesto would be drafted (Göttingen was identified as the most suitable venue for the conference, provisionally scheduled for 
spring 1995). ${ }^{71}$ As it turned out, however, the AA (M) took exception to the manifesto draft. For AFA, the issue that united militant anti-fascists was their working-class orientation: 'The middle-class Left do not want to fight. They lost the habit of fighting years ago. The struggle frightens them. So they invent excuses' ${ }^{72}$ For the AA (M), which apparently did not respond to the draft proposal until November 1995, any international network had to be rooted in a common anti-imperialism. Another point of divergence related to the struggle against patriarchy which the AA (M) viewed as integral to its politics. Relations between the two groups further soured in 1996 when the AA (M) achieved a conclusion to their trial proceedings. The charges against AA (M) were finally dropped in 1996 after the defendants promised to respect the rights of assembly in the future and to donate over 50,000 Deutsche Mark to the Mittelbau Dora Concentration Camp Memorial near Nordhausen. ${ }^{73}$ RA/London AFA interpreted their action, which brought an end to demonstrations utilising the Schwarzer Block in Lower Saxony - as surrendering meekly to the apparatus of the state. ${ }^{74}$

\section{'The First International'}

In October 1996, acting unilaterally, AFA distributed a letter proposing an international conference of militant anti-fascists in Britain over one weekend in the summer/autumn of 1997. It believed that such a conference had become essential for a number of reasons: first, to empower militant anti-fascists at international level; second, to counteract the international networks of fascists, the state and the 'conservative' Left; third, to discuss and exchange tactics, mutual support and propaganda; fourth, to build networks around football, prisoner welfare and music; fifth, to develop communication, particularly in exploiting the new 
possibilities offered by the internet; and finally, to make sure that the ideas and experiences of militant anti-fascists were promoted internationally. ${ }^{75}$ In light of positive responses from thirty-six different organisations, the first ever international conference of militant antifascists to be held in Britain was finally scheduled to take place in London during the first weekend in October 1997. Notwithstanding their differences, Bernd Langer once again returned to London and achieved some reconciliation having met with two AFA members prior to the conference. But the conference itself was not co-hosted, it was AFA's solo project. $^{76}$

AFA had booked the conference venue - the London Irish Centre in Camden, north London - in April 1997. However, the Centre cancelled the booking just days before the event. The Centre's management insisted that the Centre would lose its charitable status if it were seen to support an organisation with a history of physical confrontation against fascists. The problem was that AFA had ill-advisedly issued a press release on 18 September 1997 entitled "Militant Anti-Fascist Call to Arms". The press release stated that the anti-fascist conference would 'discuss effective tactics, including direct action, against the far right'. It also revealed that representatives from the AA (M), which had recently 'faced charges of raising a private army' and 'being a front for the Red Army Faction', would be addressing the conference. $^{77}$

Fortuitously, AFA secured an alternative venue in London at the eleventh hour. The conference drew delegates from no fewer than twenty-two organisations, including groups from Germany, Norway, Sweden, Denmark, Netherlands, France, Spain, and even the US and Canada. The main conference session was given over to discussing the draft manifesto document proposed by AFA. The opening lines of draft document had warned that, 
The spectre of fascism is haunting Europe. Having shook off the albatross of the holocaust the far-right has re-invented itself. The forces of the far-right are once again on the move. What we are actually witnessing in 1994 is the beginning of a fascist renaissance.

Even worse it is the very people who have been largely responsible for creating the problem who have assumed responsibility for providing the solution. Since 1945 the left has failed the working class in every country without exception. Dogma and failed formulas caused the problem; loyalty on redundant doctrines in the fight against fascism promise only to confound that failure. ${ }^{78}$

But whilst a minority of the large German representation was said to have 'strongly identified with the central tenets of this document', namely the call to destroy fascist influence in working-class areas, significantly, the majority (of German/Scandinavian opinion) maintained that politically, the working class no longer existed. ${ }^{79}$ For Langer, the spokesperson for the group that criticised AFA's insistence on a working-class orientation, 'building up a cult about and around the working class or labour movement' seemed 'at least in Germany, absurd [...] A working class in a historical sense does not exist anymore' for working-class identity had been destroyed by Nazism and post-war prosperity. ${ }^{80}$ Others berated AFA for failing to accept that a successful anti-fascist movement depended on recruiting support from all those who were direct targets of fascism, that is to say, immigrants, Jews, homosexuals, and women. But RA/AFA's line was that anti-fascism should not be targeted at the victims of fascism but at fascism's potential, white workingclass recruits. That AFA, as the convening group, was almost entirely male in composition did not sit well with feminist conference-goers (the registration form for the conference was even construed by some as 'sexist' - it had asked participants if they wanted to play 
football). ${ }^{81}$ London AFA did have something of a macho football culture (many supported Manchester United Football Club - 'cockney reds'). ${ }^{82}$ For AFA's Red Action contingent, these criticisms epitomised all that was wrong with contemporary anti-fascism and the wider 'progressive' Left: a multi-cultural, middle-class mind-set in which the deification of difference (race, gender and sexual preference) had replaced class equality,

This theoretical displacement of class as the primary dynamic within society for one of race, gender or sexual orientation is nothing less than a fundamental betrayal and the fount of all our misfortunes $[\ldots]$ it is the subversion of the progressive movement from within. Here is the cause of the crisis in the Left. ${ }^{83}$

In the end, with such disagreements over the relationship between class politics and anti-fascism proving so fractious, even though an impressive twenty-two groups attended, far fewer groups - nine - signed up to the international network when it was officially launched in April 1998. Key signatory groups were: AFA Hannover; ${ }^{84}$ R.O.T.K.A.P.C.H.E.N.; ${ }^{85}$ AntiFascist Platform Zaragoza; ${ }^{86}$ Toronto's Anti-Fascist Forum; ${ }^{87}$ and Anti-Racist Action from Minneapolis. ${ }^{88}$ However, the AA (M) did not join the network, and nor did AFA Scandinavia. ${ }^{89}$ The Autonome Antifa published a damning report of the conference in its newspaper, Einsatz, which critiqued AFA for trying to impose a general, common anti-fascist movement, and for concentrating exclusively on the physical confrontation of fascists on the streets. ${ }^{90}$ For sure, AFA's recourse to physical violence was undoubtedly key to its selfidentity: it had made much of a major confrontation with fascists at London's Waterloo train station in 1992. One AFA spokesperson had remarked, 'If the anti-fascist movement in Europe had implemented a policy of No Platform for fascists with the same commitment that we showed at Waterloo, then Rostock would still be just a small town in Germany'. ${ }^{91}$ 
In line with its credo that anti-fascism would only succeed if it won the battle for working-class hearts and minds, AFA continued to prescribe that a working-class orientation occupy centre-stage. This was the central message that two AFA representatives further conveyed to German anti-fascists at several meetings in Germany during July 1998. The purpose of these meetings (in Hamburg, Hannover, Buchenwald and Berlin) was to engage a wider spectrum of the German anti-fascist movement and to discuss with them the current situation in Germany from the perspective of AFA's newly-formed International Militant Anti-Fascist Network. But AFA's representatives were once more confronted by the 'mysterious disappearance of the German working class'. The belief that the German working-class had been eradicated by post-war prosperity was, unbelievably, according to AFA, a 'simple statement of fact' when it came to the German anti-fascist movement. For AFA, identification of the working class was really quite easy: for the purposes of antifascism it meant the bottom 30-40 per cent of society. To remove class from anti-fascism, AFA thought, was to deny the working class any revolutionary agency and in so doing prepared ground for the far Right. ${ }^{92}$ 'For those leading German anti-fascism', AFA explained, 'it is easier to deny the existence of the working class than it is to address the problems and needs of the working class. Therefore, whole working class communities are abandoned by the Left and become the uncontested strongholds of fascism'. ${ }^{93}$ Speaking with anti-fascist football fans in Hamburg - Glasgow AFA had established links with German anti-fascists at F.C. St Pauli during $1991^{94}$ - one fan commented to AFA that the problem was that the middle-class Left in Germany could no longer relate to working-class people because so few of them came from the working class themselves. ${ }^{95}$

What relations with German autonomists so clearly highlighted was RA/AFA's preoccupation with the working class. Apologists have argued that it was never the intention 'to make a fetish of the working class' and there was recognition that workers 'were no more 
intelligent, courageous or humanitarian than any other people'. The key point for RA/AFA was that the working class had to be the "critical dynamic driving progressive social change'. ${ }^{96}$ But for AA (M) this position did not speak to the material realities of an affluent German society. So would any German anti-fascist group adopt and implement an AFA-style, pro-working class strategy? Perhaps unsurprisingly, only groups from more deprived areas of eastern Germany, from Dresden and Cottbus were receptive to AFA's message (agreeing to form an ad-hoc committee and organise a national conference in 1999).

Even so, it was more talk than action. A solitary example of where this strategy was put into effect in Germany involved Rote Antifa (Red Antifa) in Berlin. This group, which become part of AFA's international militant anti-fascist network in 1998, had held formal discussions with AFA in London during AFA's third annual Cable Street commemoration in October $1998 .{ }^{97}$ In what was described as a 'ground-breaking' move, Rote Antifa adopted an AFA-style strategy in the de-industrialising Treptow district of East Berlin during 1999. The group felt that former East Germans were losing their "new-found loyalty to the middle class system that gave them their "freedom", and there is a general feeling of indifferent, unchannelled anti-capitalism in the air'.$^{98}$ 'The basic co-ordinates of our campaign are clear', it explained, 'no co-operation with discredited middle class organisations, a radical, working class community orientation, whilst making it clear that there is no way out of the capitalist system but revolution'. ${ }^{99}$ Rote Antifa's campaign involved posters, distributing a newspaper highlighting local problems, and staging an anti-fascist concert in Treptow. Whilst the group believed that it had made a promising start no further reports from this group were published in Fighting Talk. Regrettably the trail runs cold. Besides which, before long AFA had collapsed as a national organisation (the number of AFA branches having fallen from over twenty-five in 1999 to under five within a year); Fighting Talk ceased publication altogether with issue twenty-five in May 2001. 
Without AFA to sustain it, the 'First International' simply dissolved (although even after its demise, AFA's example would serve to inspire the Swedish group Revolutionära Fronten formed in 2002). ${ }^{100}$ The only visible remnant of the International Militant AntiFascist Network was its half-finished website. ${ }^{101}$ Three years later the AA (M) followed AFA into the annals of militant anti-fascist history when, after fourteen years in existence, it finally folded in 2004. Like AFA, German anti-fascist militants had also experienced something an identity crisis when in 2000 Germany's Red-Green coalition government clamped down on the extreme Right, suggesting that fascists were hardly 'storm-troopers of the system', thereby undermining the credibility of a system-oppositional approach.

\section{Transnational anti-fascism without fascists? The (curious) case of Anti-Fascist Action}

\section{Ireland}

One group that had also formed part of AFA's transnational network was the Dublin-based Anti-Fascist Action Ireland, first established in 1991. So what does the Irish case tell us that that German case does not? Significantly, in the Irish case, British-Irish transnational links were personal and were facilitated by Irish republican sympathies. British-German links were not, and what is more, as far as the 'national question' was concerned, German militant antifascists had categorically rejected re-unification.

The example of AFA Ireland clearly underscores the importance of personal trajectories in sustaining transnational circuits. AFA Ireland's founding members had moved to London in the late 1980s where they had become involved first with RA, and then London AFA. One their return to Dublin, a branch of Red Action was established in 1990. In 
February 1991, the visit of Jean-Marie Le Pen along with sixteen members of the European Parliament's 'Technical Group of the European Right' to Dublin Castle prompted the formation of AFA Ireland shortly afterwards. As one of the founders recalled, 'when we came back from London, there was a conscious decision made to get more organised. Up till then, we were individual anti-fascists acting ad hoc'. ${ }^{102}$

As we have already observed, support for Irish Republicanism, alongside antifascism, dominated RA's politics. In fact, given the obvious links between Ulster Loyalism and the British far Right, the causes of Irish Republicanism and militant anti-fascism were mutually reinforcing. RA would steward Republican events in Britain, such as Bloody Sunday and Troops Out marches, which would often attract the attentions of the far Right and therein offer opportunities for physical confrontation. RA would also organise regular trips to Belfast. 'Like anti-fascism', Sean Birchall explains, 'that the Irish struggle had long ceased to be fashionable among the liberal Left only added to its appeal'. ${ }^{103}$ Numerous RA members shared Irish descent; some RA members even graduated to Republican terrorism. In December 1993 Liam Heffernan, active in AFA's Northern Network at the time of his arrest, ${ }^{104}$ was sentenced to twenty-three years for conspiracy to steal explosives and to cause explosions in connection with the INLA; in May 1994 Patrick Hayes (an AFA chief steward in East London) and Jan Taylor were both sentenced to thirty years for their part in the IRA's Harrods and Ramsgate train bombings. Needless to say, establishing an AFA branch in Belfast would have been unwise for it may well have invited attention from Loyalist paramilitaries. Whilst AFA, as a 'single-issue' organisation, did not adopt an 'official' position on Ireland, it saw 'Loyalism' in Ulster (and in Scotland) as a 'parochial form of fascism' because it believed that it shared many of the same characteristics: patriotism; supremacism; discrimination; authoritarianism and anti-working class/anti-socialist practice. ${ }^{105}$ 
Establishing a branch south of the border in Dublin was a different proposition altogether. Yet oddly, there was no pressing need for a militant anti-fascist presence (proving something of the exception to the rule that anti-fascism requires a fascism to oppose). There was no organised far-Right group in Ireland; no fascist group that had any real street presence (a point that was made, somewhat ironically by AFA Ireland in a letter to the Irish World newspaper in 1997). ${ }^{106}$ Indeed, there had not been any significant fascist element on the streets of Dublin since the Architects of the Resurrection in the 1940s, a fascist-style party that had won several seats in local government elections in $1945 .{ }^{107}$ British fascist leader Oswald Mosley had moved to Ireland in the 1950s. In December 1953, his home in Co. Galway, had burnt down - rumour has it by the IRA. ${ }^{108}$ Far-Right extremism struggled to resonate in Ireland simply because it had no political space: crowded out by Sinn Féin, a nonmainstream, radical nationalist party. Not until the mid-1990s did large numbers of immigrants arrive in the Republic for the first time. Yet Irish nationalism does not sit well with anti-immigrant populism. With Irish nationalism so rooted in the struggle against 'British colonialism' and with Catholics portrayed as 'victims' of discrimination, engaging in anti-minority campaigning is at odds with Irish nationalist mythology. ${ }^{109}$

Nonetheless, it is clear that the founders of AFA Ireland felt that there was still some residual fascist threat. From the very start they adopted the twin approach of physically and ideologically confronting fascism. Sporadic physical confrontations occurred around attempts by a group of 'Blood \& Honour' skinheads to establish a presence amongst Dublin's punk scene; confrontations also occurred around attempts by a hooligan group to establish a farRight presence amongst supporters of Dublin's GAA Gaelic football team. Consistent with its parent organisation, AFA Ireland did see working-class areas as critical to its fight against the far Right. In 2002 it distributed 20,000 leaflets in the working-class constituency of Dublin South Central where the eccentric female leader of the miniscule Immigration Control 
Platform (or ICP) stood in the Irish general election. In the event Áine Ní Chonaill polled just 2.1 per cent of the vote. Yet notwithstanding its clear working-class orientation, AFA Ireland remained somewhat less sectarian than AFA in Britain. And, as one of its activists pointed out, this was an important factor in its relative longevity (it celebrated its twenty-first anniversary in 2012). So whilst AFA in Britain disintegrated as RA pushed for the adoption of electoral and local activism, AFA Ireland became a self-sustaining group, able to retain the core of people who had been involved with it from the very beginning whilst also drawing support from a variety of different Republican, anarchist and left-wing groups. ${ }^{110}$

\section{Conclusion: 'You don't have to be a Marxist intellectual to hit someone over the head with a beer bottle'}

This study was undertaken in order to determine the extent to which transnational activity was a significant feature on the landscape of militant anti-fascism in late twentieth century (Western) Europe. Whilst this article cannot claim to be comprehensive or definitive, this case study of AFA, a pre-eminent militant anti-fascist group, is certainly indicative. It suggests that transnational anti-fascism extends well beyond 1945, indeed well beyond the so-called 'era' or 'epoch' of fascism, for serious attempts were made at establishing a militant international anti-fascist network during the 1990s. It is to be hoped that this article, the first of its kind in relation to more recent manifestations of anti-fascist militancy, will serve as a platform for future studies, not only with regard to anti-fascist activities in earlier decades, but also for transnational studies of anti-fascist militancy in the present-day. What is now 
needed is a broader cross-national and transnational study of not only contemporary militant anti-fascism but also more moderate forms too.

As we have seen, the transnational connections that we have traced originated in Anglo-German co-operation and came about in response to a variety of internal and external factors: the rise of the far Right in France; the upsurge of far-Right activity in the newly reunified Germany; the perceived intervention of the state in 'criminalising' and 'isolating' militant anti-fascism; competition from rival (and more moderate) anti-fascist organisations; and internal organisational pressure. Contingency played its part too, of course. Yet we saw how significant tensions in these cross-border exchanges arose due to critical differences in social, cultural, and political orientation. AFA had maintained that anti-fascism was not 'the appropriate political arena to sort out historical arguements (sic) between anarchism and marxism; feminism and separatism; or the choosing of sides in national or international dsiputes $[\ldots]$ primacy must be given to what unites us rather than what divides us'. ${ }^{111}$ Yet AFA's insistence on the working-class as the lowest common denominator was immovable and proved just too problematic. Co-operation then became asymmetrical as AFA tried to impose its politics on others and as a result the majority drew back and disengaged from the network.

Nonetheless an international militant network was still launched. But it seems to have had little durable impact. With the exception of one militant anti-fascist group in Berlin, and AFA's sister organisation in Ireland, there is little to suggest that, contemporaneously, a common strategy was adopted. This, of course, underscores its very limitations (even for the Left which is supposedly less closely tied to the nation than the Right). Yet this does not mean that our subject does not merit serious consideration. Only by examining anti-fascism transnationally can we appreciate the fuller picture, that is to say, the broader international context in which anti-fascism operates. It calls our attention to the very complexity of this 
important subject, to what unites anti-fascists and also to what divides them, not only within nation-states but also across nation-states as well.

\section{ACKNOWLEDGEMENT}

The author would like to thank Fabian Sieber, an intern at Teesside University's Centre for Fascist, Anti-Fascist and Post-Fascist Studies, for his help in the preparation of this article.

\footnotetext{
${ }^{1}$ Red Action, editorial, issue 74, spring 1997.
}

${ }^{2}$ For accounts penned by former activists, see for example, K. Bullstreet, Bash the Fash: Anti-Fascist Recollections 1984-93 (London: Kate Sharpley Library, 2001); David Hann and Steve Tilzey, No Retreat: The Secret War Between Britain's Anti-Fascists and the Far Right (Lytham, Lancs.: Milo Books, 2003); Anon., Anti-Fascist Action - An Anarchist Perspective (London: Kate Sharpley Library, 2007); Sean Birchall, Beating the Fascists: The Untold Story of Anti-Fascist Action (London: Freedom Press, 2010); Dave Hann, Physical Resistance: Or, A Hundred Years of Anti-Fascism (Winchester: Zero Books, 2013); Horst Schöppner, Antifa heißt Angriff: Militanter antifaschismus in den 80er-Jahren (Hamburg: UNRAST, 2015); and Bernardo O'Reilly, Undertones: Anti-Fascism and the Far Right in Ireland 1945-2012 (Dublin: Anti-Fascist Action Ireland, 2012).

\footnotetext{
${ }^{3}$ For national studies written by academics, see for example, Nigel Copsey, Anti-Fascism in Britain, $2^{\text {nd }}$ edition (Abingdon: Routledge, 2016); and Gilles Vergnon, L'antifascisme en
} France: de Mussolini à Le Pen (Rennes: Presses Universitaires de Rennes, 2009). 
${ }^{4}$ For international studies written by activists, see M. Testa, Militant Anti-Fascism: A Hundred Years of Resistance (Edinburgh: AK Press, 2015); and Valerio Gentili, Antifa: Storia Contemporanea dell'antifascismo Militante Europeo (Roma: Red Star Press, 2014).

${ }^{5}$ Akira Iriye and Rana Mitter, 'Series Editors' Foreword', in Martin Durham and Margaret Power, eds., New Perspectives on the Transnational Right (New York: Palgrave-Macmillan, 2010), ix.

${ }^{6}$ For my anti-fascist minimum, see Nigel Copsey, 'Preface: Towards a New Anti-Fascist “Minimum"?', in Nigel Copsey and Andrzej Olechnowicz, eds., Varieties of Anti-Fascism: Britain in the Inter-War Period (Basingstoke: Palgrave Macmillan, 2010), xiv-xxi.

${ }^{7}$ See 'A Three Cornered Fight', Red Action, issue 67, spring 1994, 12.

${ }^{8}$ On the 43 Group, see Dave Renton, Fascism, Anti-Fascism and Britain in the 1940s (Basingstoke: Macmillan, 2000).

${ }^{9}$ See David Rose, ‘Anti-fascists regroup to signal direct action', The Guardian, 2 Sept. 1985.

${ }^{10}$ On the ANL, see Copsey, Anti-Fascism in Britain.

${ }^{11}$ For original AFA founding statement, see Red Action, issue 20, Dec. 1985, 3.

${ }^{12}$ See Shyam Bhatia and Arlen Harris, 'New group to combat race attacks', The Observer, 1 Sept. 1985. 
${ }^{13}$ Red Action, The Making of Red Action (1989), 3. Emphasis as original.

${ }^{14}$ Available online at https://www.youtube.com/watch?v=rW_niHkEXGM (last visited 29 Oct. 2015). For a flavour of the media's response to this programme, see 'Fury over AFA programme', Red Action, issue 63, July/Aug 1992, 1.

${ }^{15}$ See Nigel Copsey, Contemporary British Fascism: The British National Party and the Quest for Legitimacy, $2^{\text {nd }}$ edition (Basingstoke: Palgrave-Macmillan, 2008).

${ }^{16}$ See Mark Hayes, 'Red Action -left-wing political pariah: some observations regarding ideological apostasy and the discourse of proletarian resistance', in Evan Smith and Matthew Worley, eds., Against the Grain: The British Far Left from 1956 (Manchester: Manchester University Press, 2014), 229-46.

${ }^{17}$ See David Eimer, 'The hard left', The Guardian, 25 Nov. 1994.

${ }^{18}$ For discussion of this shift, see Nigel Copsey, 'From Direct Action to Community Action: The Changing Dynamics of Anti-Fascist Opposition', in Nigel Copsey and Graham Macklin, eds., British National Party: Contemporary Perspectives (London: Routledge, 2011), 123-41.

${ }^{19}$ Some former AFA members founded an alternative militant anti-fascist group, No Platform, but this group soon disbanded. Britain's militant anti-fascist tradition currently manifests itself in the Antifa network, an anarchist initiative formed in 2004 from No Platform, Class War and the Anarchist Federation. 
${ }^{20}$ For more on these expulsions from the SWP see Red Action, We Are... Red Action: A Short History of Red Action: Where We Came from, and Why...? (London: Red Action, n.d.).

${ }^{21}$ Cited in M. McNamara and M. Piggott, 'Interview with Red Action', originally published in Blitz Magazine (1988), available online at http://www.markpiggott.com/portfolio/1988Blitzredaction.pdf (last visited 29 Oct. 2014).

${ }^{22}$ Making of Red Action, 3.

${ }^{23}$ See Matt Seaton, 'Charge of the New Red Brigade', The Independent on Sunday, 29 Jan. 1995.

${ }^{24}$ There was a national co-ordinating committee but this met infrequently. Red Action dominated London AFA in combination with the anarcho-syndicalist Direct Action Movement (DAM) and the Trotskyist Workers' Power. In the north, only the Manchester branch had a strong RA presence. Liverpool AFA had a strong DAM contingent. The Yorkshire branches in Leeds, Bradford, Huddersfield, Sheffield and York were mainly 'nonaligned or single issue' anti-fascists including some students and trades union activists as well as some SHARP (Skinheads Against Racial Prejudice) activists. Correspondence with AFA activist, 28 Oct. 2015.

${ }^{25}$ See Fighting Fascism, Newsletter of Birmingham Anti-Fascist Alliance, no. 4, Summer 1994. 
${ }^{26}$ Activist political slang, 'antifa' refers to 'anti-fascist' and is synonymous with the militant wing of the anti-fascist movement.

${ }^{27}$ In the German language the closest equivalent to the noun 'autonomist' is autonomistisch, which was not used as a form of self-identification in Germany.

${ }^{28}$ For a history of the German autonomous movement, see Geronimo (pseud.) Fire and Flames: A History of the German Autonomist Movement (Oakland, CA: P.M. Press, 2012). This is the English translation of the book which was originally published in Germany as Geronimo, Feuer und Flamme. Zur Geschichte der Autonomen (Berlin/Amsterdam: Edition ID-Archiv, 1990).

29 Ben Mercer, 'Specters of Fascism: The Rhetoric of Historical Analogy in 1968', Journal of Modern History, 88, 1 (2016), 96-129.

${ }^{30}$ Anti-fascism is briefly discussed in the afterword to the revised English language edition of Geronimo's book but it is not discussed in the original (1990) German edition.

${ }^{31}$ Originally established in 1947 by veterans from the communist resistance, the VVN-BdA subscribed to 'legal' anti-fascism in the sense that it rejected anti-fascist militancy and called for constitutional bans on fascist organisations. For an official history of the VVN-BdA, see Max Oppenheimer, ed., Antifaschismus: Tradition, Politik, Perspektive (Frankfurt Am Main: Röderberg-Verlag, 1978). 
${ }^{32}$ Bernd Langer, Art as Resistance: Placats, Paintings, Actions, Texts from the Initiative Kunst and Kamp (art and struggle); Kunst and Kampf/Bernd Langer [Trans. By Anti-Fascist Forum], ${ }^{\text {st }}$ Engl. ed., (Göttingen: Activ-Dr. und Verlag, 1998), 53.

${ }^{33}$ Ibid., 54.

${ }^{34}$ See Ibid., 89-91.

${ }^{35}$ For more on the campaign against German reunification, see Robert Ogman, Against the Nation: Anti-National Politics in Germany (Porsgrunn, Norway: New Compass Press, 2013).

${ }^{36}$ Bernd Langer, 80 Jahre Antifaschistische Aktion (Göttingen: Verein zur Förderung antifaschistischer kultur e.V, 2012), 42.

${ }^{37}$ See Langer, Art as Resistance, 61-70.

${ }^{38}$ 2,584 recorded incidents, a rise of 74 per cent on 1991, see Panikos Panayi, Ethnic Minorities in $19^{\text {th }}$ Century and $20^{\text {th }}$ Century Germany: Jews, Gypsies, Poles, Turks and Others (London: Routledge, 2013), 255.

${ }^{39}$ Some autonomous groups still refused to participate in the AA/BO due to a residual fear of hierarchical organisation. As an alternative to the AA/BO, the Nationwide Anti-Fascist Meeting (BAT) was established. 
${ }^{40}$ See 'Discussion Paper on Autonomist Organising', AA (M), August 1991; cited in Langer, Art as Resistance, 57-8.

${ }^{41}$ See 'Zwischen Idee \& Realität. Die AA/BO im Rückblick', Antifaschistisches Info Blatt, 58, 4, Dec. 2002.

${ }^{42}$ See 'Germany Calling', Fighting Talk, issue 6, n.d., 6-8.

${ }^{43}$ See Land Brandenburg, Minsiterium des Innern, Verfassungsschutzbericht, 1993, available online at http://www.verfassungsschutz.brandenburg.de/media_fast/4055/VSB_1993.pdf, 72 (last visited 29 Oct. 2015).

${ }^{44}$ See Steffan Kailitz, Politischer Extremismus in der Bundesrepublik Deutschland: Eine Einführung (Wiesbaden: VS Verlag für Sozialwissenschaften, 2004), 126.

${ }^{45}$ See Human Rights Watch/Helsinki Human Rights Watch, “"Germany for Germans”: Xenophobia and Racist Violence in Germany', April 1995, available online at: http://www.hrw.org/reports/1995/Germany.htm (last visited 29 Oct. 2014).

${ }^{46}$ Langer, 80 Jahre Antifaschistische Aktion, 45.

${ }^{47}$ Letters page, Red Action, issue 64, Dec. 92/Jan. 93, 10.

${ }^{48}$ See Fighting Talk, issue 1, Sept. 1991, 15; and Reflexes, no. 35, Jan-Fev 1992, 28. 
${ }^{49}$ See Red Action, issue 54, p. 3.

${ }^{50}$ For more on TWAFA, see Searchlight with Tyne and Wear Anti-Fascist Association, Fascism and the Labour Movement: Facing the Threat (Newcastle: Searchlight/TWAFA, 1998), 58-60.

${ }^{51}$ See Campaign Against Fascism in Europe, 'Nazis Out', no. 1, Jan. 1992. CAFE was a short-lived group that produced a booklet entitled "Front National - A Nazi Front". This booklet claimed to prove 'conclusively' the fascist nature of Le Pen's party.

${ }^{52}$ See 'Building an international network', Fighting Talk, issue 2, spring 1992, 4-5.

${ }^{53}$ For an English translation of this leaflet, see 'The ANL ventures abroad', Fighting Talk, issue 3, summer 1992, 14-15.

${ }^{54}$ Correspondence with AFA activist, 28 Oct. 2015.

${ }^{55}$ The Anti-Fascistische Front (Antwerpen) had originally been established in 1974 by campaigners against Pinochet's regime in Chile.

${ }^{56}$ For a report on this conference, see 'Building an international network', Fighting Talk, issue 3, summer 1992, 13.

${ }^{57}$ Correspondence with AFA activist, 28 Oct. 2015. 
${ }^{58}$ See Leeds Anti-Fascist Action/AFA Infos Leeds circular, dated 25 June 1993.

${ }^{59}$ Langer, correspondence with author, 19 Oct. 2014 (translations by Fabian Sieber).

${ }^{60}$ See 'Greetings from Göttingen', Fighting Talk, issue 6, 1993, 21.

${ }^{61}$ Langer, correspondence with author, 19 Oct. 2014.

${ }^{62}$ See Rich Cross, 'British anarchism in the era of Thatcherism', in Smith and Worley, eds., Against the Grain, 133-52.

${ }^{63}$ Correspondence with AFA activist, 28 Oct. 2015.

${ }^{64}$ Cited in M. McNamara and M. Piggott, 'Interview with Red Action'.

65 'Germany Calling', Fighting Talk, issue 6, n.d., 7.

${ }^{66}$ See 'International Solidarity: Building the Links', Fighting Talk, issue 7, n.d., 7.

${ }^{67}$ On "Operation Blackshirt", see 'Codename... "Operation Blackshirt”, Red Action, issue 64, Dec. 1992/Jan. 1993, 3; and Birchall, Beating the Fascists, 285-89.

68 'Codename...', 3 
69 'Your Reality Today is Ours Tomorrow', Red Action, issue no 69, autumn 1994, 8.

${ }^{70}$ See 'The First International', Fighting Talk, issue 18, Dec. 1997, 6.

${ }^{71}$ See AFA document, 'The Spectre of Fascism: A Militant Anti-Fascist Manifesto (Draft for European Anti-Fascist Conference)', n.d.

${ }^{72}$ Ibid.

${ }^{73}$ For the official AA (M) comment on this trial, see AA (M) "1: 1 for the Autonome Antifa (M)", available online at: https://www.nadir.org/nadir/initiativ/aam/broschueren/1zu1/e2.html (last visited 29 Oct. 2015).

${ }^{74}$ Langer, correspondence with author, 19 Oct. 2014.

${ }^{75}$ See 'International Anti-Fascist Conference', Fighting Talk, issue 16, March 1997, 5.

${ }^{76}$ Langer, correspondence with author, 19 Oct. 2014.

${ }^{77}$ See AFA official press release, 'Militant Anti-Fascist Call to Arms', 18 Sept. 1997.

${ }^{78}$ AFA document, 'The Spectre of Fascism'.

${ }^{79}$ See G. O’Halloran, 'Branded', Red Action, Aug-Sep 1998, 6. 
${ }^{80}$ Langer, correspondence with author, 19 Oct. 2014.

${ }^{81}$ See comments from the Seattle-based group, United Front Against Fascism: 'London antifascist conference sabotaged by sectarian politics of its organizers', Luma Nichol, Jan. 1998. From: Freedom Socialist Party, http://www.socialism.com/drupal-6.8/?q=node/1312 (last visited 29 Oct. 2015).

${ }^{82}$ Correspondence with AFA activist, 28 Oct. 2015. Their support for Manchester United caused tensions within AFA, particularly with Leeds United fans.

${ }^{83}$ Comments by O'Halloran, 'Branded', Red Action, Aug/Sept 1998, 7.

${ }^{84}$ Established in 1983, Hannover AFA produced its own magazine, Der Rechte Band.

85 'Little Red Riding Hood', based in eastern Germany/Berlin.

${ }^{86}$ Established in the 1990 s, this group ran "Radio Antifa", an anti-fascist slot on a local pirate radio station.

${ }^{87}$ A militant breakaway group from Toronto Anti-Racist Action.

${ }^{88}$ Established in the mid-1980s and part of an Anti-Racist Action network of autonomous anti-fascists in the US and Canada. 
${ }^{89}$ AFA Scandinavia was a network comprised of Anti-Fascist Action branches in Norway, Sweden and Denmark but independent of AFA (UK).

${ }^{90}$ See 'Network Under Attack', Fighting Talk, issue 20, Aug. 1998, 8.

${ }^{91}$ Fighting Talk: Glasgow (1992).

${ }^{92}$ See Joe Reilly, 'Did You See Their Faces!?!', Red Action, Oct./Nov. 1998, 5.

${ }^{93}$ See 'Buchenwald Conference', Fighting Talk, issue 20, Aug. 1998, 7.

${ }^{94}$ For more on football links, see Fighting Talk, issue 5, 6-7 \& S. Harper, 'Back in Europe', Fighting Talk Football Special, issue 9, n.d., 6-7.

${ }^{95}$ See 'Point Blank', Red Action, Aug/Sept. 1998, 3-4.

${ }^{96}$ See Hayes, 'Ideological apostasy and proletarian resistance', p. 236.

${ }^{97}$ See ‘AFA annual Cable St Commemoration', Red Action, Dec/Jan 1998/9, 4.

${ }^{98}$ See 'Out of the Ghetto', Fighting Talk, issue 22, Oct 1999, 17.

${ }^{99}$ Ibid., 18.

${ }^{100}$ See No Quarter: Ireland's Anti-Fascist magazine, issue 5, 12. 
${ }^{101}$ See http://burn.ucsd.edu/\#imafn/organisationse.html; captured by Internet Waybackmachine (1993-2003) (last visited 29 Oct. 2015).

102 Cited in O'Reilly, Undertones, 40.

${ }^{103}$ Birchall, Beating the Fascists, 328.

${ }^{104}$ Correspondence with AFA activist, 28 Oct. 2015.

${ }^{105}$ See 'Loyalism \& Fascism', Fighting Talk, issue 4, n.d., 3-5

${ }^{106}$ See 'Far right, not organised in Ireland', letter to Irish World, 10 Oct 1997.

${ }^{107}$ See R. M. Douglas, Architects of the Resurrection: Altirí na hAiséirghe and the fascist 'New Order' in Ireland (Manchester: Manchester University Press, 2009).

108 As claimed by O'Reilly, in Undertones, 7.

${ }^{109}$ See Eoin O Malley, 'Why is there no Radical Right Party in Ireland?', West European Politics, 31, 5, (2008) 960-77.

${ }^{110}$ See report of talk given by AFA Ireland speaker at anti-fascist meeting in London, 21 April 2012, http://antifascistnetwork.org/tag/afa-ireland/ (last visited 29 Oct. 2015). 
${ }^{111}$ AFA document, 'The Spectre of Fascism'. 